\title{
Modification and Performance Evaluation of a Floating Drum Biogas Digester
}

\author{
${ }^{1}$ Uthman F. ${ }^{1}$ Balogun A. L. and ${ }^{2 *}$ Onifade T. B. \\ ${ }^{l}$ Department of Agricultural and Bio-environmental Engineering, Institute of Technology, \\ Kwara State Polytechnic, Ilorin, Nigeria. \\ ${ }^{2}$ Department of Agricultural Engineering, Ladoke Akintola University of Technology, \\ Ogbomoso, Nigeria.
}

*Corresponding author: tbonifade@lautech.edu.ng; Tel: +2348162460487

Submitted on: $18 / 05 / 2021$

Accepted on: $26 / 08 / 2021$

\begin{abstract}
Biogas is a renewable source of energy that is obtained from the anaerobic digestion of agricultural residues, animal dung, energy crops, domestic wastes and industrial wastes. These categories of waste that produce biogas are promising sources of energy and the biotechnology process of biofuel is environmentally friendly. This study aimed at modifying, fabricating and evaluating a floating drum digester. The modified floating drum digester consists of the digester tank, gas holder tank, feeding inlet pipe, gas collector outlet, slurry outlet, thermometer and hose. The gas holder tank was inserted into the digester tank while the biogas is generated in the digester tank by pressure. The biogas was produced from the mixture of cattle dung $30 \%$ and $50 \%$ plant wastes. Hence, the organic waste mixed with water in the ratio of 1: 2 for the digestion process. The digestion temperature was recorded daily for a period of 21 days at constant pressure of $1.32 \mathrm{KN} / \mathrm{m}^{2}$ throughout the experiment. The result revealed that the minimum and maximum average temperatures are 25 to $33{ }^{\circ} \mathrm{C}$. This shows that the ambient temperature affects the temperature in the digester and the amount of gas produced is a function of the accumulated temperature in the digester. It was observed that the biogas generated increase as temperature rise. The modified floating drum digester is affordable and it is recommended for small- and large-scale production.
\end{abstract}

Keywords: biogas production, cow dung, plant wastes, floating drum, renewable energy.

\section{Introduction}

Biogas is a biofuel that comprises the mixture of colourless, flammable gases obtained by anaerobic digestion of organic waste materials. Biogas is typically made up of methane (50 - $70 \%)$, carbon dioxide (30 - $40 \%$ ) and other trace gases (Ilaboya et al., 2010; Sahay and Singh, 2001). It is a renewable source of energy produced by the action of certain bacteria on organic matter in the absence of oxygen. The stored energy from the plants and animal wastes are utilized in biogas plant (or anaerobic digester) that releases gas for usage (Onwuliri et al., 2013). The digestion process that occurs in the rumen of a cow is similar to the process of anaerobic digestion in the biogas plant. Weiland (2006) reported that the energy is harvested as biogas and used as a fuel for a biogas engine which can be used in thermal generating station to produce heat energy to trigger turbines and generate electricity and alternatively the biogas could also be fed into natural gas grid or be used as a vehicle fuel. Apart from the production of food and fibre for the use of mankind; significant quantities of agricultural residue and food scraps are produced as by-product of agricultural production while bulk of these materials remain unutilized. Their disposal is a problem due to their scattered and seasonal availability (Weiland, 2006).

There are abundant agricultural residues and municipal solid wastes, whose potentials are gradually tapped for energy generation (Olorunnisola, 2007). Hence, the possibility of using such wastes for biogas production should be explored. Although, Nigeria is an oil producing country and operating a monopolistic economy driven by petroleum but it is on record that over $75 \%$ of the country population is involved in agricultural production activities; this includes cultivation of different crops such as maize, 
rice, cowpea, cassava, groundnut, cocoa and rearing of livestock; such as poultry, piggery, cattle, goat, sheep and fishery. Agricultural residues can be remains crops produced in field after harvest (primary residues) and processing residues generated from the harvested portions of crops during food, feed and fibre production (secondary residues). Agricultural residues include straw, stalks, husk, cobs, shells, sticks, peels from crops and animal dung. Food scraps are good sources of biogas, the portion of food discarded by retailers and consumers mostly produced through spoilage, substandard product and packaging failure as stated by Sahay and Singh (2001). However, with the aid of improved and proven technologies, wastes are recently turned into wealth through the provision of raw material; this improves economic growth and enhances job creation which alleviates poverty (FAO, 1996; Ngumah et al., 2013).

There is need to utilize these wastes by introducing biogas technology as an alternative means of energy for the creation of jobs to the rural areas and supply of energy for the food vendors (Mataalvarez et al., 2000). The refuse dumped all over the city or community is the unattended waste lying around that attracts flies, rats and other creatures which in turn spread diseases (Uzodinma et al., 2011), because some wastes are not properly managed, especially excreta and other liquid and solid wastes from households and the community are a serious health hazard that leads to the spread of infectious diseases (Uzodinma $e t$ al., 2011; Agunwamba, 1998). These environmental hazards will be alleviated with main reasons for the spread of renewable energy sources to increase the security of the energy supply or in other case to realize total energy independence (Ross and Walsh, 1996). Hence, high demand of energy will be accomplished if there is production of biofuel from other sources of energy generation apart from electricity generated through hydropower stations and high price of fossil fuels produced through conventional process.

It is credited that China has the largest biogas programme in the world with over 20 million biogas plants installed (Tatlidil et al., 2009). The importance of biogas is for production of energy which must be environmentally friendly as required by European Union (EU) and economically affordable because energy demand can be only solved by the harmonized application for traditional and renewable energy sources (Rich, 2010). It is therefore necessary to create biogas production and utilization system for energy and there must be focus on the environment sanitation through waste disposal (Rich, 2010). Biogas production from plant waste is a great promise in reducing destruction of trees and can spare many people in burden of gathering firewood especially in the rural areas of West Africa. Henceforth, biogas is increasingly attractive as an alternative and easily accessible source of energy since there is high demand of energy for electricity and cooking gas are at high cost (Onifade et al., 2018). Despite its promises, biogas technology is currently underexploited in West Africa and there is need for many more people to embrace this technology. One of the key advantages of anaerobic digestion is that it can convert agricultural residue to energy (fuel), fertilizers and enhance effective waste management system (Wyman et al., 1993). It also holds a great promise as a relatively cheap source of household energy that is renewable, simple to generate, convenient to access and use. Biogas production system can help in the fight against global warming by utilizing the methane obtained from organic waste as biofuel for cooking, this proffers positive solution towards economic growth rather than burning the residues and releasing its harmful gases into the atmosphere and become hazardous to living creatures (USEPA, 2015; Faizal et al., 2011).

Floating drum digester is made up of plastic material, easy to maintain, environmentally friendly and it is cost effective. The digester provides constant pressure and the gas is collected in the gas drum which rises or moves down according to the gas generated during the process. The floating dome digester is usually made of two drums (a smaller and larger drum). The larger drum is where the waste products are kept or loaded while the smaller drum which is inserted into the larger drum is the gas holder. Hence, it must be ensured during construction that all fittings are properly sealed to prevent leakage as shown in Figure 1.

There are various designs of anaerobic reactors (biogas plants) that have been used in the developed and developing countries. Some designs that are commonly used are the floating drum digester, Chinese 
LAUTECH Journal of Civil and Environmental Studies

Volume 7, Issue 1; September, 2021

model fixed dome digester, concrete model biogas plant, bag digester, anaerobic filter and the up-flow anaerobic sludge (Olaoye et al., 2014). Research reported by Uzodinma et al., (2011) was carried out on the optimization of biogas from maize bran waste and yielded low flammable biogas. The maize bran was processed further and blended with cow and swine dung, henceforth the optimization of the gas yielded was significant. Olaoye et al., (2014) also designed and fabricated a floating drum bio-digester made of metallic digestion chamber that produce slurry from waste with a greater concentration which yielded more gas. The utilization of biogas is an efficient energy source which depends strongly on its methane concentration. The biogas purification is essential in order to have more energy per volume of compressed biogas and to get rid of corrosive effect of $\mathrm{H}_{2} \mathrm{~S}$. The gas purification increases the concentration of methane which contains fuel of higher calorific value and decreases concentration of carbondioxide (Ramesh et al., 2012).

In view of this, there is need to improve on the existing digester kept in the research farm of Kwara State Polytechnic with metallic design which has corroded metallic digestion chamber with leakage parts which results to low concentration of the slurry, prolong digestion time and low gas yield. The floating drum biogas digester is modified for high production rates at low cost and made with locally available materials that allow for easy operation and maintenance. The main objective of this study is to modify the floating drum digester by reconstructing the machine frame, digestion chamber, discharge outlets and evaluate its performance so as to reduce total time of digestion, produce quality biogas, increase the digestion efficiency at low cost and achieve environmentally friendly operation of the digester.

\section{Materials and Methods}

The existing designed digester failed due to some limitations in their operational functions. The deficiencies associated with the operation of existing digester due to the shortcomings in its design were identified. The major challenges facing the existing digesting machine are generally centered on the observation that the digesting efficiency of the machine has been very low. The causes of the shortcomings observed from the existing design floating drum are the corroded part of metallic digestion chamber, low concentration of gas produced from the slurry, prolong digestion time and low gas yield.

\section{Design considerations for the improved floating drum digester}

The following factors were considered in the design of floating drum digester for optimum operation to produce high quality and quantity of gas. The factors considered include:

(i) The availability and cost of materials required (relatively cheaper than imported ones)

(ii) Ease of operation (feeding and discharging of materials)

(iii) Can be operated by one person

(iv) Size and weight of the machine

(v) Ease of Maintenance

(vi) Safety

\section{Component parts of the improved floating drum digester}

Figure 1 presents the new bio-digester which consists of these modified parts; enlarged machine frame, plastic digestion chamber and mounted thermocouple as shown in the exploded view of the machine. The enlarged machine frame was constructed to provide firm support for the digester tank and make it withstand any vibration that may occur during production. Metallic chamber was replaced with the plastic digestion chamber to prevent corrosion and reaction of the slurry with the metal which may affect the concentration of the gas yield (Ramesh et al., 2012). Mounted thermocouple is a sensor that regulates the temperature at which the gas is produced. 


\section{Description of the component parts of the bio-digester}

The floating drum bio-digester was fabricated at the workshop of the Department of Agricultural and Bioenvironmental Engineering, Kwara State Polytechnic. The schematic and exploded views of the biodigester are shown in Figure 1 while the orthographic view is presented in Figure 2. The component parts are digester tank, gas holder tank, feeding inlet pipe, gas collector outlet, slurry outlet, thermometer and hose as presented in Figure 3.

\section{Digester tank}

This is a plastic digestion drum where the plant or animal wastes to be used for biogas production are kept for the process of anaerobic digestion to take place. The volume of the tank is 265 litres.

\section{Gas holder tank}

This is also a plastic drum where the gas generated is built up in the digester tank. Its capacity is 180 litres.

\section{Gas collector outlet}

This is a small pipe located on the top of the gas holder drum that allows the passage of gas to the external reservoir (tyre-tube) or burner for cooking or heating.

Hose

This is connected to the gas outlet pipe to allow easy flow of gas from the digester to the external reservoir or directly to the burner.

\section{Inlet and Outlet Pipes}

These are made of PVC pipe both of diameter $65 \mathrm{~mm}$, with length of outlet pipe of $100 \mathrm{~mm}$ and inlet pipe, $1310 \mathrm{~mm}$. The inlet allows the loading of manure into the digester while that of outlet allows the unloading of influent or slurry from the digester.
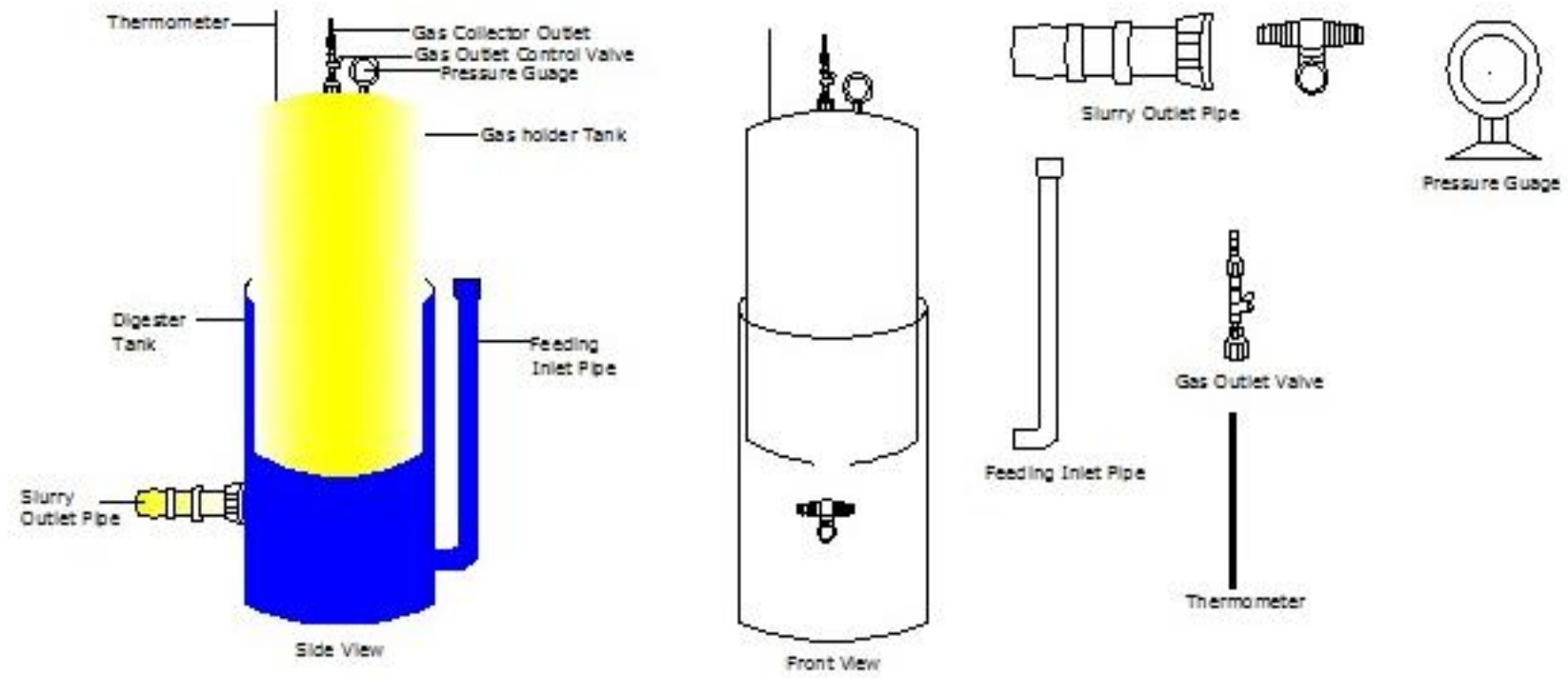

Figure 1: Schematic and exploded views of the modified floating drum digester 
LAUTECH Journal of Civil and Environmental Studies

Volume 7, Issue 1; September, 2021

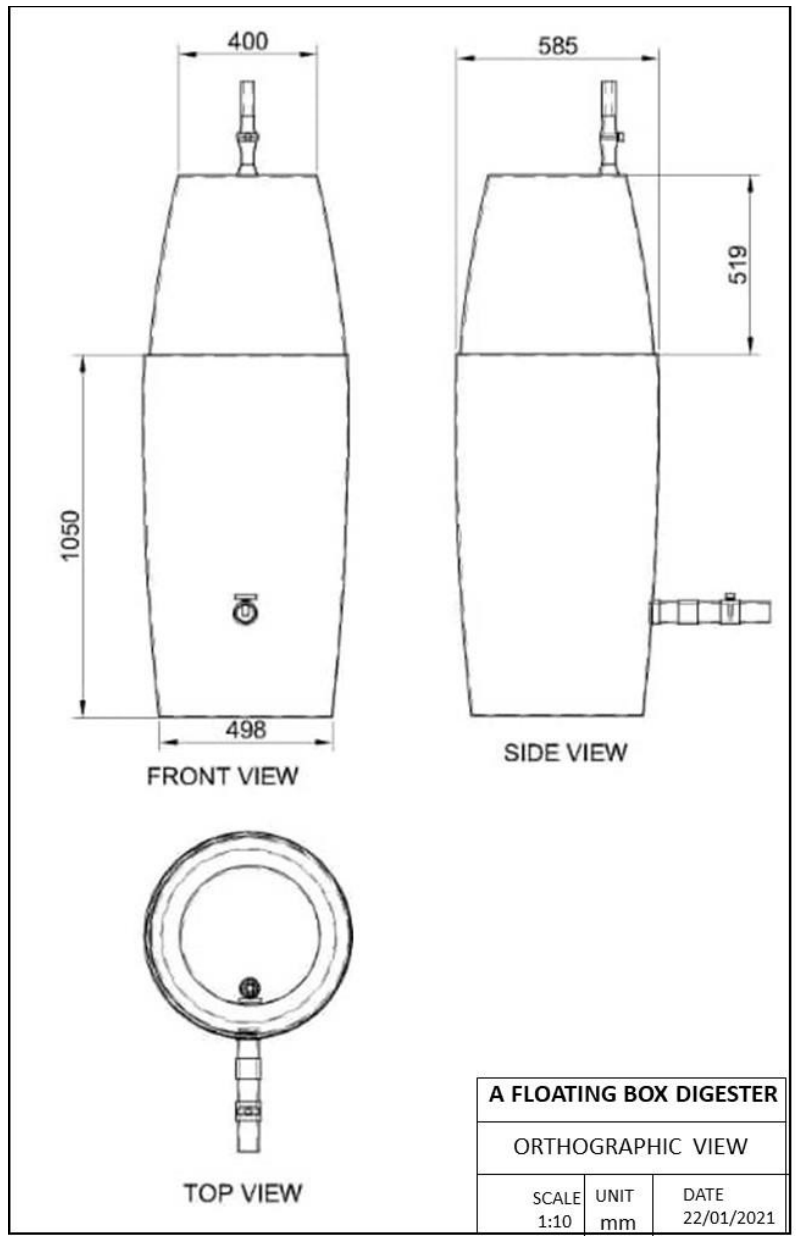

Figure 2: Orthographic view of the floating drum digester

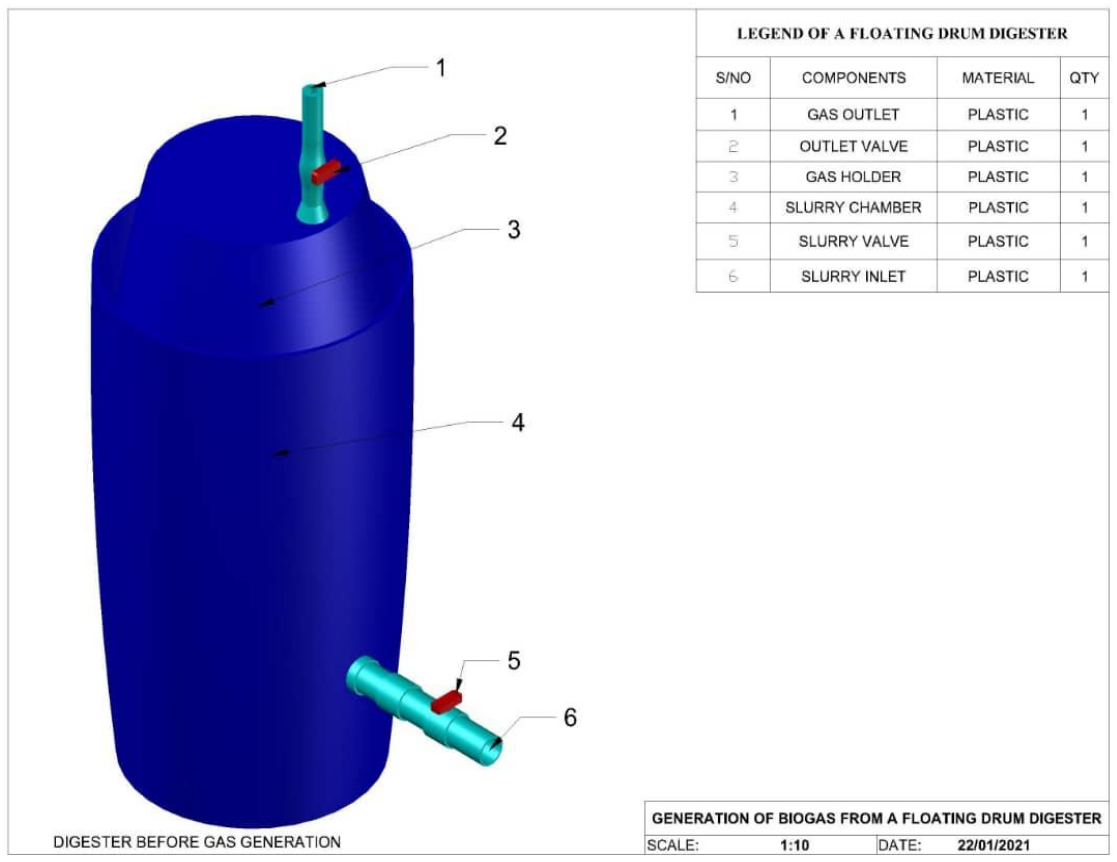

Figure 3: The modified floating drum digester 


\section{Design Analysis}

In the design of this digester, the factors considered include availability of materials, cost of materials, durability, the ease of feeding and discharging animal dung and crop residues and the collection of biogas produced. Availability of raw materials determined the type and size of the drums selected.

\section{Volume of the tank}

The biogas storage tank was made up of two cylindrical shape drums as shown in Figure 4. The large drum is meant for storing slurry while the small drum is the gas holder. The diameter and the height of the drums were computed to calculate the volume of the cylindrical drums and the total volume of the digester was determined as follows;

$V_{L}=\pi r^{2} \mathrm{~h}=$ The total volume of larger drum

$r=$ radius of the digester, $0.295 \mathrm{~m}$

$\mathrm{h}=$ height of the digester, $0.970 \mathrm{~m}$

$$
\begin{aligned}
& =\pi(0.295)^{2}(0.970) \\
& V_{L}=0.265 \mathrm{~m}^{3} \\
& =265 \text { litres }
\end{aligned}
$$

$V_{s}=\pi r^{2} h=$ The total volume of smaller drum

$r=0.262 \mathrm{~m}$

$\mathrm{h}=0.840 \mathrm{~m}$

$V_{s}=\pi(0.262)^{2}(0.840)$

$$
\begin{aligned}
V_{S} & =0.181 \mathrm{~m}^{3} \\
& =181 \text { litres }
\end{aligned}
$$

$V_{T}=\pi r^{2} \mathrm{~h}=V_{L}+V_{S}$

$V_{T}=$ Total volume of digester, $\mathrm{m}^{3}$ or litres

$=265+181$ litres

$=464$ litres

\section{Design for Pressure to be generated}

The pressure $\mathrm{P}$, generated inside the digester that made the digestion to occur was calculated using equation 4 as follows;

$$
\text { Pressure }=\frac{F}{A}=\frac{N}{m^{2}}
$$

$F=$ Force exerted in the process $=m g$

$m=$ mass of the materials $(\mathrm{kg})$

$g=$ acceleration due to gravity $=9.81 \mathrm{~m} / \mathrm{s}^{2}$

$A=$ surface area of the tank, $\pi r^{2} \quad r=$ radius of the drum $=0.295 \mathrm{~m}$

$m=37 \mathrm{~kg}$

$A=3.142\left(0.295^{2}\right)$

$$
A=0.734 m^{2}
$$

Pressure, $P=F / A$

$$
F=37(9.81)=362.97 \mathrm{~N}
$$

$A=\pi r^{2}=0.734$

$P=362.97 / 0.273$

$$
=3464 \mathrm{~N} / \mathrm{m}^{2}
$$




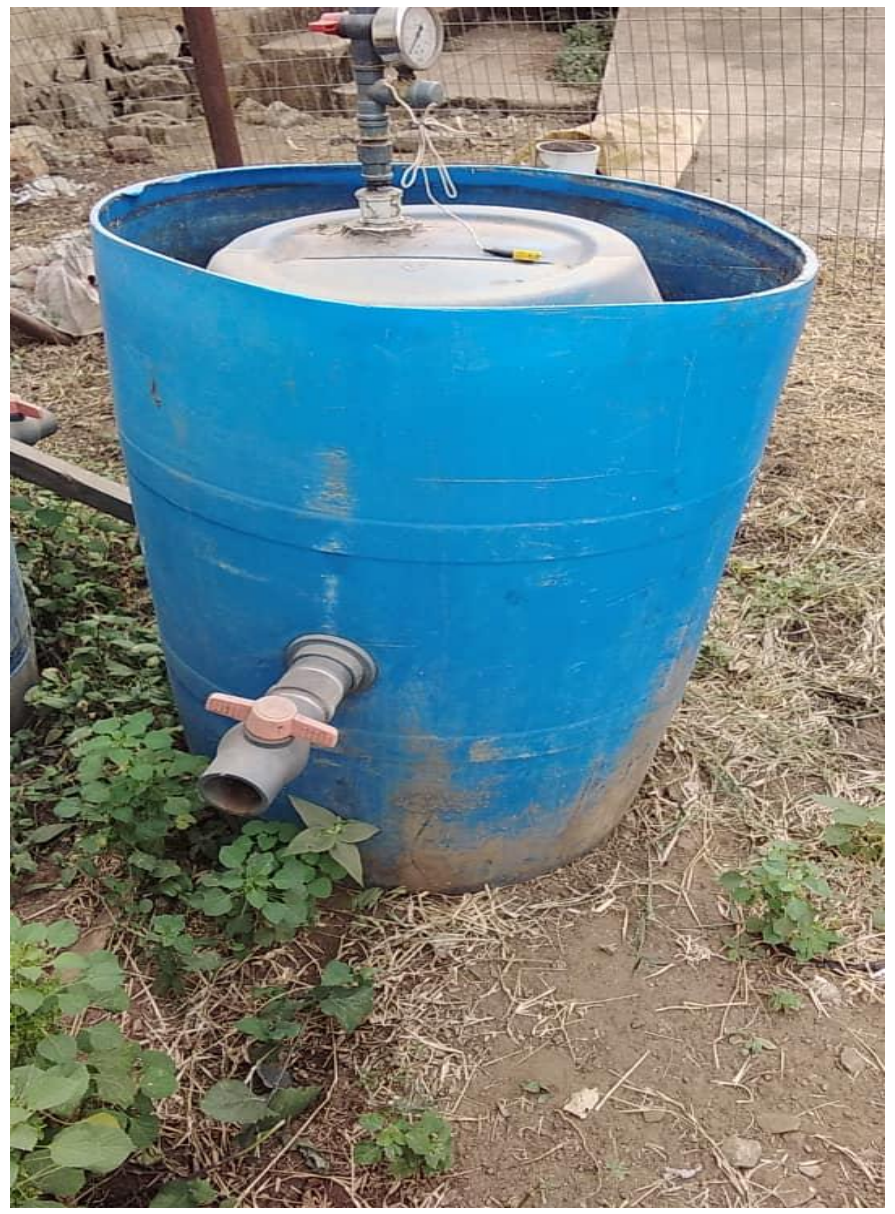

Figure 4: The pictorial view of the floating drum digester

\section{Sample Preparation}

The materials used for the experiment were cattle dung and crop residues such as banana peel, mango peel, orange peel, maize husk. The animal dung and crop residues used for the experiment were collected from Ipata Abattoir and Mandate Market Adewole in Ilorin, Nigeria. The dried dung was sorted to remove unwanted particles and then the sample was weighed using electronic balance, Mettler Toledo P.B 153 of $0.01 \mathrm{~g}$ accuracy. The crop residue was prepared for digestion process, the materials were cut into smaller sizes and the impurities were removed before loading into the biogas digester for effective and efficient anaerobic processes. The samples were cut into pieces at crop processing laboratory during the initial stages of the anaerobic digestion. Series of remedial actions were taken to ensure the machine's functional requirement for its intended use. The cattle dung and crop residues were mixed in the ratio of 3:5 and then mixed with water in the ratio of 1: 2 of water (Olaoye et al., 2014; Ngummah et al., 2013).

Essential reactions must occur during the digestion process to ensure that there is an effective biogas production, such reaction to be observed include: formation of methane caused by bacteria which are sensitive to $\mathrm{pH}$ of the slurry. Suitable condition for fermentation stage of normal gas production occurs when the $\mathrm{pH}$ of the slurry reaches a point between 7 and 8 . The bacteria that aid anaerobic digestion process in the digester cannot survive at the $\mathrm{pH}$ greater than 8 . The optimum temperature that is suitable for bacteria reaction ranges from 35 to $40{ }^{\circ} \mathrm{C}$. The gas production decreases as the processing temperature falls between $20{ }^{\circ} \mathrm{C}$ and $10{ }^{\circ} \mathrm{C}$ (Ramesh et al., 2012). The biogas purification was done to remove the impurities present in the raw biogas then desulphurizer was applied in this process to remove the Hydrogen Sulphide $\left(\mathrm{H}_{2} \mathrm{~S}\right)$, water and other impurities. The biogas produced was tested using a modified biogas burner. The gas was collected in the storage bag via the hose from the bag to the biogas stove. The 
flame of the biogas stove was luminous and the effectiveness of the flame was tested for by boiling water. A $200 \mathrm{ml}$ of water was heated on a biogas stove filled with raw and purified biogas so that boiling duration could be known.

\section{Principle of operation of the bio-digester}

The mixture of cattle dung and crop residues was fed through the inlet pipe to the digester tank in order to make the slurry. The main digester tank is filled with slurry, whereas the gas holder is left free for the collection of gas. The waste undergoes anaerobic degradation in the presence of water with the gradual evolution of bio-gas. The bio-gas collection starts in the floating gas holder drum. It is observed that rise in the pressure of the gas speeds up the formation of biogas and more biogas is collected into the gas holder drum. The wastes and water slurry are left in digester for a period of 21 days as reported by researchers (Olaoye et al., 2014). The leftover slurry made after the biogas extraction is rich in nitrogen and phosphorus compounds and thus can be used as manure in agriculture. Thermometer was placed at the middle of the biogas digester to monitor the temperature. The temperatures of the slurry during digestion process were measured thrice daily (morning, afternoon and evening) and were recorded for 21 days. The calculated pressure for the anaerobic process was given as $3464 \mathrm{~N} / \mathrm{m}^{2}$. This was the pressure generated inside the digester that made the digestion to occur thoroughly. The collected raw and purified biogas was filled in a stove and the gas was used to boil water to determine heating period of the raw and purified biogas that was produced by the modified floating drum digester.

\section{Results and Discussion}

Results from the design analysis showed that force required for the digestion of the materials inside the large drum was $362.97 \mathrm{~N}$. The volume of small drum (gas holder tank) was 181 litre while that of larger drum (digester tank) 265 litres. The total volume of bio-digester floating tank was 464 litres. The total weight of substrate introduced into the digester was $104 \mathrm{~kg}$. The quantity of gas produced inside small drum after digestion process was $1.8 \mathrm{~m}^{3}$. The pressure needed for gas production was found to be 3464 $\mathrm{N} / \mathrm{m}^{2}$. Table 1 shows the daily temperature reading and the average temperature obtained in the floating drum bio-gas digester. The reading was taken for a period of 21 days. During the period of the experiment, it was observed that the slurry temperatures were within the optimum range for bacteria growth. The temperature reading was obtained using liquid in glass thermometer by inserting it on the gas holder tank permanently. The minimum and maximum temperatures varied from $25^{\circ} \mathrm{C}-33{ }^{\circ} \mathrm{C}$ and the amount of gas produced is a function of the accumulated temperature in the digester. It was observed that as the digestion temperature increases the gas production rises. The average digestion temperature falls within the range of 25 and $33{ }^{\circ} \mathrm{C}$.

Results of the gas constituents obtained from the raw and purified biogas are presented in Table 2. The values of methane produced are 58.31 and $78.20 \%$ from raw and purified biogas process respectively. Purified gas has higher methane content than the raw gas while other constituents such as Nitrogen hydride, Hydrogen Sulphide and Carbon-dioxide decrease after purification process of the biogas. This is in accordance with the research reported by Ramesh et al., (2012) that gas purification increases the amount of methane while other gas constituents decrease. The concentration of methane increased to enable fuel of higher calorific value and decrease the concentration of other constituents which might contain impurities. The results of the heating period of water boiled with raw and purified biogas were 3.19 and 2.07 minutes, respectively. The reduced heating time indicated that the calorific heating value of the purified biogas was higher than raw biogas (Ramesh et al., 2012). 
LAUTECH Journal of Civil and Environmental Studies

Volume 7, Issue 1; September, 2021

Table 1: Daily and average temperature reading in the floating drum Digester

\begin{tabular}{|c|c|c|c|c|}
\hline Time: & $8 \mathrm{am}$ & $1 \mathrm{pm}$ & $6 \mathrm{pm}$ & \\
\hline $\mathrm{S} / \mathrm{N}$ & & Temperature & ${ }^{\circ} \mathrm{C}$ & Mean \\
\hline 1 & 21 & 28 & 25 & 25 \\
\hline 2 & 23 & 30 & 30 & 28 \\
\hline 3 & 24 & 31 & 32 & 29 \\
\hline 4 & 25 & 31 & 24 & 27 \\
\hline 5 & 25 & 30 & 30 & 28 \\
\hline 6 & 24 & 32 & 32 & 29 \\
\hline 7 & 22 & 27 & 30 & 26 \\
\hline 8 & 27 & 36 & 27 & 30 \\
\hline 9 & 25 & 31 & 28 & 28 \\
\hline 10 & 23 & 29 & 30 & 27 \\
\hline 11 & 22 & 32 & 28 & 27 \\
\hline 12 & 24 & 33 & 30 & 29 \\
\hline 13 & 25 & 34 & 31 & 30 \\
\hline 14 & 24 & 28 & 30 & 27 \\
\hline 15 & 26 & 32 & 34 & 31 \\
\hline 16 & 24 & 30 & 30 & 28 \\
\hline 17 & 23 & 30 & 31 & 28 \\
\hline 18 & 24 & 28 & 31 & 28 \\
\hline 19 & 25 & 25 & 32 & 31 \\
\hline 20 & 28 & 30 & 32 & 30 \\
\hline 21 & 30 & 32 & 38 & 33 \\
\hline
\end{tabular}

Table 2: Results of Raw and Purified Biogas

\begin{tabular}{lll}
\hline Gas & Raw \% & Purified \% \\
\hline Methane, $\mathrm{CH}_{4}$ & 58.31 & 78.20 \\
Nitrogen hydride, $\mathrm{NH}_{3}$ & 0.63 & 0.21 \\
Hydrogen Sulphide, $\mathrm{H}_{2} \mathrm{~S}$ & 1.76 & 0.18 \\
Carbon-dioxide, $\mathrm{CO}_{2}$ & 40.1 & 24.72 \\
\hline
\end{tabular}

\section{Conclusions}

The floating drum bio-digester has been modified with locally available materials. Biogas technology was achieved with the organic waste digested in the modified bio-digester. The raw biogas obtained was purified. The purified biogas contained higher methane content than raw biogas and hence purified biogas resulted to less heating time than raw biogas. The biogas produced is an essential bio-energy that can be used by small- and large-scale end users. 


\section{References}

Agunwamba J. C. (1988). Solid Waste Management in Nigeria: Problems and Issues. Journal of Environmental Management 22(6): 849-856.

FAO (Forest and Agricultural Organization) (1996). A System Approach to Biogas Technology "Biogas Technology a training Manual for Extension". A handbook, Intermediate Technology Publications. Southampton, London WCCB 4HH, UK.30-34.

Faizal A., Wan Daud, W.M.A., and Sahu, J.N. (2011). Optimization and characterization studies on biooil production from palm shell by pyrolysis using response surface methodology, Journal of biomass and bioenergy 35:3604-3616.

Ilaboya, I.R. Asekhame, F.F. Ezugwu,M.O. Erameh,A.A.Omofuma, F.E. (2010). Studies on biogas generation from agricultural waste: analysis of the effects of alkaline on gas generation, World Application Science Journal 9:537-545.

Mataalvarez J, J. Mace, S. and Labres, P. (2000). Anaerobic digestion of organic solid wastes -an overview of research achievements and perspectives, Journal of Bioresource and Technology 74:316.

Ngumah C. C., Ogbulie J. N., Orji J. C. and Amadi E. S. (2013). Biogas Potential of Organic Waste in Nigeria. Journal of Urban and Environmental Engineering. 110-116.

Olaoye J.O, Oyeleke I. F. and Adeniran K.A. (2014): Design, Fabrication and Testing of a Floating Drum Bio-digester. Proceedings of the International Soil Tillage Research Organization (ISTRO), Nigeria Symposium, Akure, Nigeria. pp. 149-161.

Olorunnisola A. (2007). Production of Fuel Briquette from Waste Paper and Coconut Husk mixtures. Agricultural Engineering International CIGR-Journal. 11:50 - 55.

Onifade, T. B., Wandiga S. O., Bello I. A., Jekayinfa S. O. and Harvey P. J. (2018): Impact of Renewable Technology on Lignocellulosic Material of Palm Fruit Fibre: Strategy for Climate Change and Adaptation. Springer Journal of Climate Change; University Initiatives in Climate Change and Adaptation, 18:175-201.

Onwuliri F. C., Onyimba L.A., and Nwaukwu I.A., (2013). Generation of Biogas from Cow Dung. Journal of Bioremediation and Biodegradation. Doi: 10:4172:2155-6199.

Ramesh, B.N. Abyot, T. Rao, B.A. (2013): Biogas purification, compression and Bottling. Global Journal of Engineering Design and Technology. 2(6): 34 - 38.

Rich D. 2010: Micro- Scale Biogas Production: A Beginners Guide. A Project of the National Center for Appropriate Technology. ISSN 1-800-346-9140 pp 10; www.attra.ncat.org.

Ross C.C. and Walsh J.L. (1996). Biogas Source and Characteristic. In Handbook of Biogas Utilization, Second edition, U.S. Department of Energy, Tennessee Valley Authority, Muscle Shoals, Alabama, pp 56.

Sahay, K.M and Singh, K.K. (2001). Unit Operation of Agricultural Processing station on the Microbial Flora of Animal Wastes 2: Digestion and Modelling of Process Parameters (ISSN) 1819-3579.

Tatlidil F., Bayramoglu, Z. and Akturk, D. (2009). Animal Manure as one of the main Biogas Production Resources: Case of Turkey. Journal of Animal and Veterinary Advances. 8 (2): 2473-2476.

U.S. Environmental Protection Agency (2015). Bio-Based Products and Chemicals, Waste-to-Energy Scoping Analysis, Office of Resource Conservation and Recovery, 2015.

Uzodinma E.O., A.U and Enwere N.J. (2011). Optimization of Biogas Fuel from Maize (Zeamays) Bract Waste: Comparative Study of Biogas Production from Blending Maize Bract with Biogenic Wastes. American Journal of Food and Nutrition. ISSN 2157-1317, pp 1-6.

Weiland, P. (2006). Biomass Digestion in Agriculture: A successful Pathway for the Energy Production and Waste Treatment in Germany. Journal of Engineering in Life Science: 6:20-24.

Wyman, C.E. and Goodman, B.J. (1993). Biotechnology for production of fuels, chemicals and materials from biomass, Application of Biochemistry and Biotechnology, 39:41-59. 